УДК 130.2:793.2

ORCID: 0000-0001-8563-646X

Лариса Бабушка, кандидат філософських наук, дочент, докторант Національної музичної академії Украӥни ім. П. І. Чайковського, вул. Архітектора Городецьького, 1-3/11, Київ, 02000, Украӥна

Larisa Babushka,

Ph.D. in Philosophy, Associate Professor, Doctoral Candidate, Ukrainian National Tchaikovsky academy of music, 1-3/11 Architect Gorodetsky St., Kyiv 02000, Ukraine

\title{
ФЕСТИВАЦІЯ КУЛЬТУРОТВОРЧОСТІ В ПРОСТОРІ ПОВСЯКДЕННОСТІ
}

Мета роботи. 3'ясувати специфіку фестивації як феномену сучасної культури та іiі вплив на моделі культуротворчості, які формувалися в ході еволюційного розвитку свята, оскільки вони тією чи іншою мірою відображають як теоретичні, так і практичні проблеми сьогодення. Методологія дослідження передбачає застосування діалектичного, компаративного та соціокультурного підходів, які на засадах взаємодоповнення покладено в основу розвідки. Наукова новизна дослідження полягає в тому, що вперше здійснений соціокультурний аналіз фестивації та досліджена логіка становлення іï нового формату в світоглядних проекціях глобалізму та альтерглобалізму. Висновки. Поперше, фестивація - сучасна святкова культура - спрямовує до такої особливості глобалізаційних та альтерглобалізаційних стратегій як гіперболізації впливу повсякденності на форми й напрямки активності людини, домінуючими рисами якої є утилітарно-прагматичний характер універсальних структурних елементів. По-друге, відмінність буденної культури від повсякденної полягає в тому, що перша характеризується виконанням рутинних щоденних обов'язків, у той час як повсякденна культура постає актуалізацією всього обсягу культури в повсякденній практиці. По-третє, фестивація є особливою формою культуротворення, утримуючи свою поліфункціональну природу, проявляється в гібридності сучасної та традиційної культур.

Ключові слова: фестивація, культуротворчість, повсякденність, буденність, глобалізм, альтерглобалізм.

Festivation of cultural creation in the space of everyday life. Purpose of Research. To clarify the specifics of the of festivation as a phenomenon of modern culture and its influence on the models of cultural creation that were formed during 
the evolutionary development of the holiday, since they to some extent reflect both theoretical and practical problems of our time. The research methodology assumes the use of dialectical, comparative and sociocultural approaches, which, on the basis of complementarities, are the basis of the article. The scientific novelty of the research is that for the first time a sociocultural analysis of festivation was carried out and the logic of the formation of its new format in the worldview projections of globalism and alterglobalization was investigated. Conclusions. First of all, festivation - is a modern festive culture-directs to such a feature of globalization and alternative globalization strategies as an exaggeration of the influence of everyday life on the forms and directions of human activity, the dominant features of which are the utilitarian and pragmatic nature of universal structural elements. Secondly, the difference between everyday culture and everyday life is that the former is characterized by the fulfillment of routine daily duties, while everyday culture appears as an actualization of the whole volume of culture in common practice. Third, festivation is a special form of cultural creation, retaining its polyfunctional nature; it manifests itself in the hybrid nature of modern and traditional cultures.

Key words: festivation, culture-making, everyday life, commonness, globalism, alterglobalization.

\section{Фестивизация культуротворчества в пространстве} повседневности. Цель работы. Выяснить специфику фестивации как феномена современной культуры и ее влияние на модели культуротворчества, которые формировались в ходе эволюционного развития праздника, поскольку они в той или иной степени отражают как теоретические, так и практические проблемы современности. Методология исследования предполагает применение диалектического, сравнительного и социокультурного подходов, которые на основании взаимодополнения являются базисом статьи. Научная новизна исследования заключается в том, что впервые осуществлен социокультурный анализ фестивизации и исследована логика становления ее нового формата в мировоззренческих проекциях глобализма и альтерглобализма. Bыводы. Во-первых, фестивизация - современная праздничная культура - направляет к такой особенности глобализационных и альтерглобализацийних стратегий как гиперболизации влияния повседневности на формы и направления активности человека, доминирующими чертами которой являются утилитарно-прагматический характер универсальных структурных элементов. Во-вторых, различие будничной культуры от повседневной заключается в том, что первая характеризуется выполнением рутинных ежедневных обязанностей, в то время как повседневная культура предстает актуализацией всего объема культуры в повседневной практике. В-третьих, 
фестивизация является особой формой культуротворчества, удерживая свою полифункциональную природу, она проявляется в гибридности современной и традиционной культур.

Ключевые слова: фестивизация, культуротворчество, повседневность, обыденность, глобализм, альтерглобализм.

Bcmyn. Фестивація - сучасна святкова культура - феномен XXXXI століття, що потребує власного диференційного підходу та узагальнення світоглядного бачення в контексті глобалізаційних та альтерглобалізаційних вимірів культуротворення. Фестивація ніколи не займала позиції забутості чи то витіснення на периферію ціннісних смислів буття, історично була й залишається центром дослідницького інтересу та наукових симпатій мислителів як сучасності, так і минулого.

Фестивація культуротворчості відноситься до універсальних категорій, що синтезує креативні, суб'єктивні, нормотворчі, трансцендентальні, віртуальні, естетичні, релігійні виміри тощо. Розуміння сучасної святкової культури спрямовує до такої особливості глобалізаційних та альтерглобалізаційних стратегій як гіперболізація впливу повсякденності на форми й напрямки активності людини, домінуючою рисою якої $\epsilon$ утилітарно-прагматичний характер універсальних структурних елементів.

Наукова новизна дослідження полягає в тому, що вперше здійснений соціокультурний аналіз фестивації в царині повсякденності та досліджена логіка становлення іï нового формату щодо світоглядних проекцій глобалізму та альтерглобалізму.

Складна природа феномена фестивації зумовлює вектор на аналіз культурних практик, досвідів, поглядів, які формувалися в ході еволюційного розвитку свята, оскільки вони тією чи іншою мірою відображають як теоретичні, так і практичні проблеми свого часу. Однак у вимірах глобалізму вони (практики, досвіди тощо) мігрують із одних національних лакун в інші, змінюючи при цьому семантику. Забезпечення самоідентичності людей у колективі, етнонаціональному топосі відбувається, завдячуючи святковій культурі, точніше, їх присутностізалучення до дійств, що продукують вироблення й транспортування певних ідей, ідеалів і цінностей. Водночас простір глобалізму та альтерглобалізму стимулює наступні тенденції сучасної святкової культури як поява наднаціональних, надконфесійних свят, результуючим фактором яких постають інтегративна та консервативна функції. Водночас, утримуючи соціокультурну природу й культуротворчий потенціал, 
фестивація є актуальною незалежно від періоду історичного розвитку суспільства та типу культури. Моделі культуротворчості пов'язані 3 ритуалом, ідеацією й святом як ритуалізованим медіакультурним простором й свідчать про те, що дана проблема має масштабне поле адеквацій і потребує синтетичного культурологічного самовизначення.

Мета та завдання розвідки - 3'ясувати специфіку фестивації як феномену сучасної культури та ії вплив на моделі культуротворчості, які формувалися в ході еволюційного розвитку свята, оскільки вони тією чи іншою мірою відображають як теоретичні, так і практичні проблеми сьогодення. Відповідно для реалізації поставленої мети передбачається вирішити наступні завдання:

- обгрунтувати специфіку фестивної культури в контексті глобалізаційних та альтерглобалізаційних тенденцій сучасності;

- з'ясувати семантичний простір понять «повсякденність», «буденність», «святковість» як модусів культури;

- розглянути проблему співіснування та взаємозв'язку «повсякденної культури», «буденної культури та «фестивної культури».

Методи дослідження визначені специфікою об'єкта дослідження фестивацією, а також обумовлені вищеозначеним розумінням мети та передбачених завдань. Щодо принципів дослідження першорядними виступають принципи світоглядного плюралізму, синтезу, взаємозв'язку, взаємозалежності, взаємозумовленості царин соціокультурного буття.

Заявлені принципи знайшли своє втілення в діалектичному, постмодерністському, компаративістському, філософськокультурологічному підходах.

Діалектичний підхід дозволяє виявити іманентну логіку генези фестивації в сучасному культуротворчому просторі повсякденності. Постмодерністський підхід передбачає врахування насамперед глобалістських та альтерглобалістських тенденцій у площині культури, що впливають на характер як буденного, так і святкового часу, реформують локальну й національну ідентичність мільйонів українців. А саме: домінування транснаціональних інтересів у суспільстві; проникнення та взаємовплив культур різних народів; стирання меж між святковими культурами; віртуальна й психологічна відкритість кордонів між державами; тенденція до створення уніфікованої моделі щодо способу життя, мистецтва, одягу, харчування тощо, зразком котрих дедалі частіше продукується глемкультура, а носіями є представники «селебрітіс». Компаративістський підхід зумовлений залученням порівняльного аналізу розуміння та проявів свята в різних світоглядних культуротворчих парадигмах. 
Філософсько-культурологічний підхід до феномену свята здійснювався 3 урахуванням різних позицій i аспектів. Відтак, пріоритетною джерельною базою дослідження поставатимуть ті позиції, котрі мають безпосереднє відношення до заявленої проблеми й вибірково аналізуються автором впродовж розвідки. Дослідник подає перелік тих авторитетних імен, джерел та проблем, які дотичні до теми, надалі в розгорнутому форматі аналізує вибіркову літературу, що безпосередньо пов'язана $з$ вищеокресленою метою й завданнями, а саме, співіснування та взаємозв’язок фестивної - повсякденної - буденної - культур в умовах глобалізму та альтерглобалізму. Відтак, формуванню методологічних засад дослідження сприяли наступні ідеї: свято як один 3 важливих аспектів соціальної поведінки, як «розрив»у повсякденності, що формують певну систему культурних кодів та символів розглядали П. Бергер, Г. Блумер, Ф. Броделя, К. Гірц, І. Гоффман, Т. Лукман, Дж. Мід, А. Шюц; святкова й повсякденна реальність у проекції культури представлена у розвідках О. В. Золотухіна-Аболіної, Н. Д. Мостицької; в аспекті мистецьковидовищних форм сучасної культури - К. Станіславської; у протиставленні до буднів як опозиції сакрального та профанного розглядав Е. Дюркгейм; гіперфестивний характер сучасної святкової культури, що зливається 3 повсякденністю осмислював французький мислитель Ф. Мурей; вплив на свято релігійних, політичних, соціальних ідей, які домінували в різні періоди часу представлені в розвідках М. Бахтіна, К. Жигульського, М. Хренова, В. Савчука. Проблеми культуротворчості, iї функціонального потенціалу розглядаються крізь призму сучасного дискурсу глобалізації, зокрема у працях 3. Баумана, У. Бека, Е. Гідденса, У. Еко.

Результати. Виклад основного матеріалу. Як правило, традиційне розуміння свята як особливого культурного феномену розглядається як вихід з буденності насамперед завдяки протиставленню його щоденній праці, будням. Контрастність 3 буденністю завжди підкреслювала величність й урочистість традиційних свят на відміну від сучасних, де новостворені свята зливаються 3 повсякденністю. Існування множинності вимірів реальності (повсякденної, трансцендентної, святкової, буденної, віртуальної тощо) не є спеціальною рефлексією даного дослідження, однак, на думку автора, варто зосередити увагу на розмежуванні й можливостях точок перетину наступних царин людського буття як буденна - повсякденна - святкова складові. Оскільки дослідження фестивної (святкової) культури базується в царині повсякденності, то доречним $\epsilon$ предметне окреслення топосу останньої. Якщо буденна й святкова царини $є$ видимо й значимо протилежними, то буденна й 
повсякденна сфери, будучи також різновекторними за своєю суттю, нерідко піддаються ототожненню, синонімічності в тих чи інших конотаціях дослідників.

Царина повсякденності, очевидно, корелює 3 буденністю, навіть більше, остання є невід'ємною ії складовою, однак розбіжність між ними $є$ доволі значимою. Повсякденність є своєрідним «життєвим станом» чи емпіричним життям людини, що фіксує наше перебування в чуттєвотілесно-предметних координатах, наділена ціннісним смислом й сакральним характером, оскільки постає для кожного з нас одним з найближчих модусів існування. Адже наше буття проживається у площині повсякденності. Буденність, за звичай, виступає процесом рутинізації самої повсякденності, що характеризується одноманітністю й монотонністю, подекуди втратою справжньої ідентичності з природою й соціальним середовищем, відтак, дисгармонією емоційно-психологічного стану людини й суспільства. Буденна культура характеризується виконанням рутинних щоденних обов'язків, в той час як повсякденна культура постає актуалізацією всього обсягу культури в повсякденній практиці, що в свою чергу дозволило дослідникам диференціювати останню на релігійну, політичну, світську (культури), які здатні поєднуватися в межах одного дня, заявляючи про себе як актуальні. Звісно, культура повсякденності не лише не виключає зі свого топосу такої структурної складової як буденна культура, а й постає іiі своєрідною Alma mater, на якій то актуалізується, то притлумлюється остання, поступаючись місцем іншим реальностям, до прикладу, святковій реальності.

Свято як особливе культурне явище $\epsilon$ виходом із буденності насамперед за допомогою протиставлення його щоденній праці, як зауважувалось раніше. Під час свята зазвичай рутина витісняється, поступаючись місцем відпочинку, залученню до священного і розваг. Відповідно, в святкові дні долається телеологічний принцип, прагматично цілеспрямованої діяльності щодо «вічної турботи» створення умов життя. Знаменита гайдеггерівська «турбота» як основна характеристика буття-всвіті в ці відведені особливі дні дарує людям перепочинок. Турбота постає справою буднів. Натомість свято характеризує найширший контекст сакрального як перманентного процесу, що відбувається в культурі, а саме, єднання трансцендентного, прогностичного, чуттєвого образу та досвіду бачення реалій буття.

Свято, утримуючи терапевтичну функцію, примиряє протилежності, з одного боку, синтезує механізми прийняття дійсності, адаптації до неї, дає можливість змиритися з об'єктивно сформованими обставинами, а 3 іншого - допомагає народитися новому, вітаючи оновлення, слугує людині 
для кращого розуміння дійсності, яка нерідко постає невиразною у своїй новизні. На думку Х. Кокса, свято «загострює свідомість історії й водночас дає відпочинок від неї» [4, с. 127].

Феномен повсякденності поставав об’єктом особливої уваги французьких вчених Школи Анналів, зокрема, Фернана Броделя, який запропонував одну 3 перших концепцій «культури повсякденності», де розглядав систему первинних та вторинних потреб та гармонізації власних психічних реакцій на вплив зовнішнього світу. Діалектика ідей теорії Ф. Броделя простежується у праці Ж. Бодріяра «Система речей», де автор припускає, що повсякденність може розглядатися як рухоме утворення 3 нестійкою структурою, здатною до моментальних змін. Для класичної святкової культури притаманне підпорядкування вже заданій традиції й ритуалу, що оберігає базові системоутворюючі ідеї й цінності культури. На думку сучасного культуролога Н. Д. Мостицької, «історично свято - це діяльність у відношенні до священних предметів, ідеалів, що розгортається в заданому ритуалі й обряді. Тобто, святкове дійство максимально ритуалізовано й не передбачає свободи самовираження і довільної форми діяльності, як і свободи комунікації. Воно за своєю суттю константно, завдяки ритуалізованій комунікації» [7, с. 132]. Далі проводиться дослідницею думка, що повсякденність $є$ більш рухливою щодо формування устаткованих правил, оскільки передбачає постійний пошук нових взаємодій зі світом, реакцію на плинні умови життя. Відтак, Н. Мостицька залишається на позиціях розуміння святковості як константності, а повсякденності як динамічності буття.

Отже, святкова комунікація, опираючись на ритуалізовані форми задає стійкі конструкції хронотопу - часу і простору. У той самий час як повсякденність має властивість рухливості, мінливості або ризомності щодо структури тимчасових i просторових характеристик. Проблеми повсякденності торкався й М. М. Бахтін у відомій праці «Творчість Франсуа Рабле і народна культура середньовіччя й Ренесансу». Розглядаючи сміхову, карнавальну культуру, автор протиставляє їх загальноприйнятій офіційній системі цінностей, яка визначає духовні орієнтири повсякденного існування людини в середньовічному суспільстві. При цьому сміхова культура виступає як особливий комунікативний простір, що дозволяє знаходити лакуни пошуку свободи в непростих умовах повсякденних практик тогочасності.

Дослідниця О. В. Золотухіна-Аболіна в розвідці «Повсякденність: філософські загадки», зауважує, що «в святі, сакральному за своєю глибинною суттю, людина радіє благам реального світу, в якому вона 
живе, і дякує провидінню за досконалість життя (нехай воно насправді навіть недосконале!), але водночас ніби розігрує в емпіричних матеріальних умовах ситуацію Раю: відсутність важких зусиль, вільне споживання хорошої їжі, веселощі, пісні, танці. Досвід свята, якщо він дійсно відчутий i прожитий, надає людині величезного позитивного впливу: це досвід життєствердження, радості й визнання законності й осмисленості тієї рутинної повсякденності, яка передує святу і неминуче слідує за ним. Тому що свято виходить з буденності і повертається в неї, воно іiі висвітлює, надає ій форму і ритм, організовує темпоральний простір повсякденності [3, с. 65].

Протилежної точки зору дотримувався В. Савчук, полемізуючи 3 Геноном, зауважував, що наскільки б не було стійким карнавальне щеплення до дискурсу про свято, проте вважати його породженням чи то ексцесом буднів було б занадто прямолінійно, оскільки воно не $\epsilon$ особливим, хай і якісно відмінним, станом буднів; він не $\epsilon$ похідна їх монотонності, де в граничній точці нетерпимості виявляються деструктивні й невпорядковані компоненти психіки людини [9, с. 46-47]. Його міркування спираються на наступний факт: в давньогрецьких, діонісійських, елевсінських, самофракійських містеріях учасники вірили у воскресіння вже втраченої на той час гармонії - часу «золотого століття». Отже, сутність свята полягає не в перверсії повсякденності, осілого і упорядкованого життя, а у воскресінні того, що передувало йому, що було спочатку: вічно нове відчуття шляху, руху. Щодо здійсненності попередньої форми життя говорить ще та обставина, що божества давнини, витісненні 3 повсякденності, допускаються імперією свята у вигляді персонажу або маски, образу, яких обирають й відтворюють. Вони постають провідниками в інший світ тілесних станів. Відтак, попередні форми життя проступають у святі як свідчення його автентичності та сакральності. Міфологічне існування у найближчому буденному просторі проблематизується, в той самий час, як сакральне, що оточує нас, стає повсякденним. Щодо постмодерністської ситуації, для якої характерна еклектика, десакралізація традиційного простору культури, спроба осягнення глибин смислу поступається місцем очевидній констатації.

Присутність свята в просторі повсякденності засвідчує факт його єднання як у гуляннях, карнавалі, сміхові, танцях, піснях, водночас, і в скорботі, сягаючи до історичних свідчень про етнографічні спостереження із різних частин світу, де «не так вже й давно, неможна було уявити собі монарших весіль i народних забав великого стилю поза стратами, тортурами чи то певного аутодафе» $[8$, с. 446$]$. 
Традиційне розуміння свята завжди потребувало опертя на смисложиттєву подієвість у долі роду, спільноти, держави. Звільнення від праці й буднів, подолання роз'єднаності не є безформними, вони мають свій ритм та логіку. Саме тут розкриває себе режисура свята, яка виходить iз особливості психіки людини, яка охоче впадає в піднесений стан серйозної урочистості, страху, розчулення, жалю, а далі мігрує до радості, веселощів, єднання в спільності, яка відсутня в повсякденності.

Згідно 3 думкою Г.-Г. Гадамера, «... свято й торжество 3 усією очевидністю відрізняється тим, що початковий поділ тут відсутній, навпаки, настає загальне єднання. Щоправда, ця відмінна риса святкування пов'язана з певним мистецтвом, яким ми володіємо вже недостатньо добре. Це мистецтво проведення свята. I тут люди віддалених часів і меншою мірою розвинених цивілізацій значно перевершували нас» [2, с. 308]. Тут швидше мова йде про амбівалентність архаїчного суспільства, яка виражалась в синкретизмі єдиного i множинного, цілого i частини, природного і надприродного, живих і спочилих, поняття часу від його переживання тощо.

Особливим досвідом свята є вміння свідомо відтворювати святковий стан внутрішнього світу незалежно від зовнішніх причин (від конкретних особистих до офіційних соціокультурних урочистостей). Незважаючи на те, що свято є колективною подією, цей досвід не варто абсолютизувати та зводити до офіційних дат, позначених календарем, оскільки святковий стан або інакше «внутрішне свято» може з'являтися наодинці з самим собою як раптова радість.

Щодо сучасної фестивної культури, на наш погляд, варто внести деякі уточнення. Інший зріз досвіду долучення до сучасної Festive культури, який продукується, носить гіпертрофований характер. До прикладу наведу, святковий настрій у дітей, на думку батьків (самі не відаючи того), що беруть за зразки прояви глем-культури (культури гламуру), повинен бути не те, що циклічним, а неминуче постійним, поза перервністю, для відтворення безперебійного «еталонного» стану/відчуття. Жодного дня поза святковим настроєм, однак подібний тотальний підхід і притлумлює, зрештою, розмиває межі між святом й не-святом, відчуття особливої атмосфери піднесеності й достеменних веселощів. Навіть «внутрішнє свято», яке не детерміноване «подієвістю» чи «датністю» передбачає чуттєвий перманентний процес. $\mathrm{y}$ іншому випадку відбувається непомітна підміна потреб святкового стану на потребу в сильних емоціях. 
Заслуговує уваги й позиція Ю. М. Лотмана, розуміючи культуру як текст, він розглядає повсякденність у нерозривності з глобальними явищами, що характеризується ним як неподільність буттєвого i побутового, тобто актуалізуються онтологічні основи повсякденності як умови людського існування. Колись подібна потреба реалізовувала себе в тому, що «всупереч правилам дуелі на поєдинок нерідко збиралася публіка, як на видовище» [5, с. 101], бо останнє приваблювало завше зір. Сьогодні ця потреба реалізується у підпільних змаганнях бойових мистецтв, що проводяться на контактному рівні, де нерідкі серйозні травми і випадки, які живлять азарт глядачів-гравців, що ставлять ставки на переможця.

Примітно те, що й I. Кант, фіксуючи суперечності, вказує на природний стан, вихід з якого досягається не стільки на засадах розуму, стільки перманентним уподібненням архаїчному стану в дні ритуалів i свят, коли усувається цивілізована надбудова над природою, відпускаються заборони й відтісняються будь-які соціальні регулятиви, норми, коли непередбачувано знаходить вихід життєва енергія. Культуролог В. Савчук у своїй праці «Кров і культура» розмірковує про важливість свята крізь призму життєдайності символу, що «повертає людину і дає їй проникнути в реальність архаїчних образів, відчуттів, регулятивів і того особливого простору, в якому зовсім інша топографія місцевості, тимчасові ритми, наповненість подій, мова, інтенсивність бажань й інші об'єкти задоволень. Будучи прямим спадкоємцем ритуалу, свято увібрало всі його найбільш дієві властивості, його логіку розвитку: зростання хаосу, невизначеності, тривог, втоми і абсурду, трагізму; потім злиття 3 ними (хаосом і невизначеністю): несамовитість, сміх, танець, торжество низу, відмова (перевертання) від встановлених норм, заборон і табу - харчових, моральних, ідеологічних, естетичних, релігійних, травестизм ролей і статі - чоловічої, жіночої, невизначеної (курсив мій. Л. Б.); надалі воскресіння природного і соціального Космосу, циклу, порядку, норми, доцільності й корисності [9, с. 54].

Американський соціолог Джон Вілсон щодо зростання соціальної напруженості, яка супроводжується вибухом громадських заворушень, вводить поняття «ритуальних повстань», особливо це стосується спортивних змагань. Переломлення соціальної напруги можна побачити не тільки в «кривавих святах» на стадіонах, а й, як стверджує Дж. Вілсон, в організації рядовими громадянами таких форм відпочинку, які $\epsilon$ «виразом бунту проти існуючої соціальної системи», до них відносяться народні театри, фестивалі, фольклорна музика, джазові ансамблі [9, с. 58]. 
Як в ритуалі, так i святі негативні прояви людської натури, перемагаються в міметичному вигляді. Свято, як i ритуал, будучи вихідцями з архаїки, є неперебутніми формами, в яких уможливлюється нейтралізація негативних проявів людської природи за допомогою мімезису. Філіп Мурей у своєму полемічному есе «Festivus festivus» застерігає, що в дистанції «від Homo festivus до Festivus festivus випадає те, що помітить навіть п’ятилітня дитина, це Номо...» [11]. Іншими словами, зникає Людина, реалізується проект завершення Людини, а 3 нею i людського. Атрактивність свята припиняється тоді, коли відбувається втрата людяності, як окремої людини, так і співтовариства в цілому. Людина стає більш обмеженою, менш пристосованою й позбавляється, на думку теолога Харвея Кокса, відчуття свого важливого місця й призначення в космічному житті.

Висновки. Підводячи підсумки дослідження щодо аналізу специфіки фестивації у просторі повсякденності та їі впливу на сучасні моделі культуротворчості, сформулюємо наступні узагальнення.

По-перше, фестивація - сучасна святкова культура - спрямовує до такої особливості глобалізаційних та альтерглобалізаційних стратегій як гіперболізації впливу повсякденності на форми й напрямки активності людини, домінуючими рисами якої є утилітарно-прагматичний характер універсальних структурних елементів.

По-друге, відмінність буденної культури від повсякденної полягає в тому, що перша характеризується виконанням рутинних щоденних обов'язків, в той час як повсякденна культура постає актуалізацією всього обсягу культури в повсякденній практиці, що в свою чергу дозволило дослідникам диференціювати останню на релігійну, політичну, світську культури.

По-третє, фестивація є особливою формою культуротворення, утримуючи свою поліфункціональну природу, проявляється у гібридності сучасної та традиційної культур. Моделі культуротворчості пов'язані 3 ритуалом, ідеацією й святом як ритуалізованим медіакультурним простором й свідчать про те, що дана проблема постає простором синтетичного культурологічного самовизначення.

1. Бодрияр Ж. Система вещей. Москва : Рудомино, 1999. С. 95.

2. Гадамер Г.-Г. Актуальность прекрасного. Москва : Искусство, 1991. 308 с.

3. Золотухина-Аболина Е. В. Повседневность: философские загадки. Киев: НикаЦентр, 2006. 256 с. 
4. КоксХ. Праздник шутов: Теологический очерк празднества и фантазии (Реферативное изложение И. Б. Роднянской)// Современные концепции культурного кризиса на Западе. Москва, 1976. С. 127.

5. Лотман Ю. М. Роман А. С. Пушкина «Евгений Онегин» : Комментарий : пособие для учителя. Санкт-Петербург : Искусство-СПБ, 1995. С. 472-762.

6. Мюрэ Ф. После Истории. Фрагменты книги // Философия. Философские проблемьл духовной жизни. Литература Европь 20 в. / пер. с фр. Н. Кулиш // Иностранная литература. 2001. № 4. С. 224-241.

7. Мостицкая Н. Д. Праздничность и повседневность в проекции константности и динамичности бытия культуры. Философская мысль. 2016. № 4. С. 129-143.

8. Ницше Ф. К генеалогии морали. Полемическое сочинение : в 2 m. T. 2. Москва: Мысль, 1990. С. 446.

9. Савчук В.В. Кровь и культура. Санкт-Петербург: Издательство СанктПетербургского университета, 1995. 180 c.

10. De Backer C., Nelissen M., Vyncke P., Braeckman J., Mcandrew F. Celebrities: from Teachers to Friends: A Test of Two Hypotheses on the Adaptiveness of Celebrity Gossip // Human Nature. 2007. Vol. 18. № 4. P. 334.

11. Muray P. Festivus festivus: conversations avec Élisabeth Lévy: format Kindle. Paris: Fayard, 2005. Vol. 490. URL: https://www.amazon.fr/Festivus-festivus-Conversations\%C3\%89lisabeth-Documents-ebook/dp/B005OKST7W [Accessed 01 march 2018].

\section{References}

1. Bodriyar, Zh. (1999). System of things. Moscow: Rudomino.

2. Gadamer, G.-G. (1991). The relevance of the beautiful. Moscow: Iskusstvo.

3. Zolotuhina-Abolina, E. V. (2006). Daily life: philosophical riddles. Kyiv: Nika-Tsentr.

4. Koks, X. (1976). Fools' Festival: Theological sketch of festivity and fantasy. Moscow.

5. Lotman, Yu. M. (1995). Alexander Pushkin's novel «Eugene Onegin»: Commentary: Teacher's Manual. St. Petersburg: Iskusstvo-SPB.

6. Myure, F. (2001). After the History. Fragments of the book. Inostrannaya literatura, 4, pp. 224-241.

7. Mostitskaya, N. D. (2016). Festivity and everyday life in the projection of the constancy and dynamism of the existence of culture. Filosofskaya myisl, 4, pp. 129-143.

8. Nitsshe, F. (1990). To the genealogy of morals. Polemical composition. In 2 vol. Vol. 2. Moscow: Myisl.

9. Savchuk, V. V. (1995). Blood and Culture. St. Petersburg: Izdatelstvo S.-Peterburgskogo universiteta.

10. De Backer C., Nelissen M., Vyncke P., Braeckman J., Mcandrew F. (2007). Celebrities: from Teachers to Friends: A Test of Two Hypotheses on the Adaptiveness of Celebrity Gossip. Human Nature. Vol. 18. № 4. P. 334.

11. Muray P. (2005). Festivus festivus : conversations with Élisabeth Lévy. Paris: Fayard [online] Available at: https://www.amazon.fr/Festivus-festivus-Conversations\%C3\%89lisabeth-Documents-ebook/dp/B005OKST7W [Accessed 01 march 2018]. 